\title{
INTERNATIONAL REVIEW OF ECONOMICS
}

ANd MANAGEMENT

\section{FACTORS AFFECTING BRAND LOYALTY IN FOOTBALL: AN APPLICATION ON "THE BIG FOUR" FOOTBALL CLUBS IN TURKISH SUPER LEAGUE ${ }^{\dagger}$}

Gizem TOKMAK ${ }^{\ddagger}$

Ramazan AKSOY ${ }^{\S}$

\begin{abstract}
The research aims to investigate the factors affecting brand loyalty in football industry. In order to achieve this aim, the loyalty of the supporters of Beşiktaş, Fenerbahçe, Galatasaray, and Trabzonspor called as "The Big Four" since they have the highest brand value in Turkish Super League were investigated. By using quota sampling method, 662 students of the faculty of economics and administrative sciences of Bulent Ecevit University in 2013-2014 spring period were reached and questionaire technique was applied to the sample. The students who were supporters of another football clubs except from The Big Four, and who were non supporters were eliminated and 557 students were found to be the supporters of The Big Four. In the research, the variables were tested via Multiple Linear Regression Analysis. As a result of the research, benefits variable from brand associations and identification variable were found to be the most effective variables on psychological commitment towards the football clubs. The other result indicated that psychological commitment variable and benefits variable from brand associations were found to be the most effective variables on behavioral loyalty towards the football clubs.
\end{abstract}

Keywords: Brand Loyalty, Brand Associations, Identification, Football.

JEL Classification: M31, M37, M39.

Jel Codes: M31.

\footnotetext{
† This paper was procured from Gizem Tokmak’s Master thesis (Tokmak, 2014) prepared under the supervision of Ramazan Aksoy at the Department of Business Administration in Bülent Ecevit University.

‡ Bülent Ecevit Üniversitesi, gizem.tokmak89@hotmail.com

§ Bülent Ecevit Üniversitesi, ramazanaksoy@beun.edu.tr

Date of submission: 31.03 .2016

Date of acceptance: 10.11.2016
} 


\section{INTRODUCTION}

Football is one of the industries in which the concept of brand and brand loyalty are fundamental. In football industry, not only the football club, but also individual footballers, the coach, and the league that the football club performs can be considered as brands. The football players, the coach, the uniforms, the stadiums, and brand associations such as functional or social benefits provided by the football club are important for a football supporter to develop loyalty towards the football club. Managing these tools effectively brings a strong brand image to the football clubs. As Bauer et al. (2005) stated that brand image is an important factor that affects brand loyalty, therefore the football clubs should decrease the effect of physical and humane factors that can negatively affect the brand image of the clubs, or the clubs should develop these factors to improve the clubs' brand images.

In order to survive in the industrialized football sector, the football clubs should alter their consumers' psychological commitment to behavioral loyalty so that they can gain material earnings from these consumers. Thus, it becomes fundamental for a football club to obtain brand loyalty of its consumers. In the research, it was aimed to reveal the factors affecting brand loyalty towards football clubs. Beşiktaş, Fenerbahçe, Galatasaray, and Trabzonspor named as the "Big Four” in Turkish Super League were specified as research field for the research. The results indicate that especially the intangible factors such as identification with the football club and psychological commitment to the football club are effective variables on behavioral loyalty of the supporters.

\section{LITERATUR REVIEW AND HYPOTHESES}

\section{II.I. Football As a Product and Brand}

Football as a sport product can be defined as a service activity that provides benefits to its spectators, attendees, and the sponsors. Football as a product has tangible and intangible features as each sport products do have. The tangible features of football include the football itself, the footballers, the coaches, the football team itself, the rival football teams, and the league such as Turkey Super League and La Liga. On the other hand, the intangible features of football include the feeling of victory and pride, the excitement and pleasure reviving from being champion or winning the match. The tangible and intangible features of football are the most important components that affect the brand value of a football club (Brooks, 1994).

According to Deloitte report (2014), Real Madrid F.C. has the highest brand value which means the highest sum of financial entities. The report also indicates that Real Madrid has the highest 
number of followers in social media. This also indicates that Real Madrid F.C. has the highest brand awareness. In some circumstances, brand equity exceeds brand value. For instance; according to the subject Deloitte report (2014), although Barcelona F.C. has lower brand value than Real Madrid has, the club has higher brand awareness in social media increasing the brand equity of Barcelona. Deloitte report (2014) indicates that even if the sum of the both Galatasaray and Fenerbahçe football clubs' brand values are lower than the brand values of Bayern Munich F.C. and Manchester United F.C., the social media awarenesses of Galatasaray and Fenerbahçe are threatening for the mentioned football clubs. Besides, Galatasaray and Fenerbahçe are important as they are the first Turkish football clubs from outside the Europe that entered to the list since the season 2005-2006. In this success of Galatasaray and Fenerbahçe, the development of the country, the passions and the brand loyalty of the supporters towards the football clubs, and the development of the infrastructure of football in the country play important roles. For instance; Turk Telekom Arena is one of the best stadiums in Europe which increases the brand value of Galatasaray.

\section{II.II. Brand Loyalty in Football}

Brand loyalty is described in two manners including psychological and behavioral points of views. Behavioral brand loyalty means that a customer repetitively and consistently purchase a brand and it is supposed that this purchasing behavior of the customer incrementally strenghtens the relationship between the brand and the customer (Assael, 1998). According to this point of view supporters, the customers who systematically purchase the same brand, become loyal customers of the mentioned brand (Odin et al., 2001:76). On the other hand, psychological brand loyalty consists of an internal tendency to the brand in addition to iterative purchasing behavior of the customers towards brand (Gounaris and Stathakopoulos, 2004:284).

When a sport team is evaluated as a product to be marketed, team loyalty stands for a maintaining loyalty to a definite team (Salman, 2008:100). In that vein, the loyalty to a football club can be defined as a maintanining loyalty to a definite football club. To constitute a brand loyalty in football is difficult to manage since football as a product is intangible and inconsistent. The main reason why the football product is inconsistent is that human factor showing changeable features is intensive in football product. The inconsistency in football product which means the performance of a football team is not constant may result in weakening the brand image which may also result in weakening brand loyalty towards the mentioned football club.

\section{II.II.I. Psychological Commitment-Behavioral Loyalty Relationship in Football}

Dick and Basu (1994) indicate that commitment attitude is a precessor of loyalty. Another similar point of view indicates that loyalty appears in a consequence of commitment attitude (Jacoby 
and Chesnut, 1978). Psychological commitment can be evaluated as a process where a customer firstly becomes loyal to a brand in a cognitive manner, and then he/she subsequently becomes loyal to the brand in a sensitive and intentional manners (Back, 2005). Oliver (1999) indicates that after the mentioned three phases completed, behavioral loyalty occurs as the forth phase. Oliver (1999) also indicates that the loyalty concept originated from the commitment attitude constitudes a resistance on consumers' behaviors shifting against the rival brands' marketing activities. For instance; the supporter who has a strong attitude towards the football club has a robust resistance against changing loyalty behaviors. This also increases psychological commitment of the supporter towards his/her football club. Within this context, Bee and Havitz (2010) examined the relationship between psychological commitment and behavioral loyalty in football, and concluded that psychological commitment and resistance to change mediated the effect of fan attraction and involvement on behavioral loyalty. Tachis and Tzetzis (2015) discriminated the concepts of psychological commitment and attitudinal loyalty and found out that both psychological commitment and attitudinal loyalty affect behavioral loyalty of the sport fans to the soccer teams. With the support of these results, it can be considered that psychological commitment is the precessor and reason of behavioral loyalty in football. The hypothesis indicating this statement was described below:

H1: Psychological commitment has a statistically meaningful effect on behavioral loyalty.

\section{II.II.II. Identification-Brand Loyalty Relationship in Football}

Sport Spectator Identification Index is often used in the researches which are conducted to measure brand loyalty in football. For a person identified with the football team that he/she supports, the football team becomes one of the components constituting his/her identity (Belk, 1988; Madrigal, 2000). The identified person embraces the football team's success and then he/she becomes proud of it. Identification does not only occur in the case of success. The identified person also embraces the failure of the football team as well. For instance; the research conducted by Genar (2004) indicates that the number of identified people who do not prefer to meet with his/her friends when the football team that they support fails is remarkably high. This result indicates that the identified people feel ashamed because of the team's failure. This is also an indicator of identification with the team.

The identification level makes differentiation between the concepts of favourableness typologies such as spectatorship and fanatism among football consumers. This distinction can be performed by the Sport Spectator Identification Index as long as this index makes a distinction that differs the supporters for the level of their favourableness (Wann and Branscombe, 1995). 
Identification makes people voluntarily struggle for the brand they identified with, attract with the other brand community members, and psychologically loyal to the brand (Bhattarcharya ve Sen, 2003). A person who identifies with the brand community, tend to exaggerate the similarities with the community members, and decrease the discrepancies with the people who are outside the community (Arkonaç, 2001). This may explain why the supporters of the same football club have the same synergy, and consider other football clubs' supporters as enemies; since identification with a football club stands for psychological connection between a supporter and a football club (Wann and Wiggins, 1999).

Football spectators are guarantees for their football clubs' economic entities as they go and watch their football clubs' matches at the stadium or by using some media channels (Erdoğan, 2008). In that vein, it can be said that identification level with a football club also fundamental for the football club to maintain its economic entity, since the identification level of a supporter alters from spectatorship to fanatism (Trail and James, 2001).

Çiftyıldız (2015) investigated the relationship among the identification of the supporters with the football clubs, psychological commitment and purchasing intentions and determined that there were a positive relationship among the variables. Enginkaya (2014) investigated the relationship among the attitudes and purchasing intentions of the supporters toward the sponsor brands, and identification with the football clubs and determined that there was a relationship between the identification with the football clubs and attitudes toward the sponsor brand. In addition, Torlak et al. (2014) investigated the relationship among the identification level of the supporters with the football clubs, quality perception toward the licenced products of the clubs and purchasing intentions, and determined that identification level was more effective on purchasing intention than it was on quality perception of the supporters. On the other hand, Wu et al. (2012) seperated identification in two parts which were identification as a fan-team level and identification as a fan-player level and determined that team identification was the major determinant of fans' loyalty intentions, however, player identification had an indirect effect on fans' loyalty intentions. In addition, Stevens and Rosenberger (2012) determined that fan identification, following sport and involvement positively influenced fan loyalty.

As the literature supports that identification with the football clubs affects loyalty, the hypotheses were established below:

H2a: Identification has a statistically meaningful effect on psychological commitment.

H2b: Identification has a statistically meaningful effect on behavioral loyalty. 


\section{II.II.III. Demographical Factors-Brand Loyalty Relationship in Football}

There are limited researches directly indicating the relationship between demographical factors and brand loyalty. For instance; Kurtuldu and Çilingir (2009) found in their research conducted in cigarette sector that gender, marital status and age variables of the consumers created no differences on the tendency and behaviors of the consumers towards brand loyalty while occupation status, income level and education level created statistically meaningful differences on the level of brand loyalty. The researches made in football industry indicating whether demographical factors create any differences on brand loyalty provide that men are more identified and psychologically committed to the football clubs than women are, as the income level decreases, the psychological commitment increases, and the psychological commitment of the group in the age of 55 and above and in the age of 18 and below is found to be higher than the other age groups (Salman and Giray, 2010; Demirel et al., 2007). The hypotheses established in that vein are indicated below:

H3a: Demographical factors have a statistically meaningful effect on psychological commitment.

H3b: Demographical factors have a statistically meaningful effect on behavioral loyalty.

\section{II.II.IV. Brand Associations-Brand Loyalty Relationship in Football}

Everything about brand come to the consumers' minds constitutes brand connotations (Aaker, 1991:109). According to Keller (1993:5), brand connotations constituting brand image comprise of the factors related to the product, factors unrelated to the product, benefits, and attitudes. In this research, the effects of the factors related to the product, factors unrelated to the product and benefits on brand loyalty are investigated.

The perceived benefit of a brand is divided into three categories including functional, experimental, and symbolic benefits. Functional benefits are about internal features of the brand and satisfy physical and security needs of the customers. Experimental benefits are mostly related to the unrelated features of the product and satisfy the intangible needs such as amusement of the consumers (Keller, 1993:4). On the other hand, symbolic benefits are also related to the unrelated features of the product just as the experimental benefits, they are also related to some other motives of the customers such as self-expression, social acceptance, and self-trust (Odabaşı, 2006:130). The mentioned benefits revive from the satisfaction of the consumers and psychological needs of the consumers which brings brand loyalty.

Factors related to the product stand for the sum of the features that the customers are in expect from the product (Keller, 1993). Factors related to the product increase the product's performance 
and satisfy the customer's expectations from the product in this way. In this point of view, it can be said that factors related to the product for a football club are the factors that increase the football club’s performance (Gladden ve Funk, 2002:57). In that vein, the factors related to the product for a football club are determined as individual footballer, game of the team, staff of the team, the coach, and the management of the football club (Gladden ve Funk, 2002:57; Bauer vd., 2005). These factors can also be counted as tangible and intangible motivational factors of a football club. Funk et al. (2012) determined that sport consumer motivational factors explained $60 \%$ of the variance in loyalty towards the football club in some aspects such as game attendance, media usage, wearing team related clothing and purchasing team related merchandise. Dependent on these results, the following hypotheses were established:

$\mathrm{H}_{4} \mathrm{a}_{1}$ : Factors related to the product have a statistically meaningful effect on psychological commitment.

H4a2: Factors related to the product have a statistically meaningful effect on behavioral loyalty.

Factors unrelated to the product are described as the factors which have no effect on the product performance; but have an effect on the purchasing and consuming of the product (Keller, 1993). Factors unrelated to the products comprise of the external factors about consumption and purchasing. For a football club, the factors unrelated to the product are determined as the logo, the colours of the club, the stadium, the old success of the club, the organisational culture and values, and the supporters of the club (Gladden ve Funk, 2002; Koç, 2008). Aycan et al. (2009) determined that some tangible and intangible motivational factors such as the event attraction, the program convenience and physical environmental factors had significant effect on identification with the team affecting brand loyalty.

$\mathrm{H}_{4} \mathrm{~b}_{1}$ : Factors unrelated to the product a have statistically meaningful effect on psychological commitment.

$\mathrm{H}_{4} \mathrm{~b}_{2}$ : Factors unrelated to the product have a statistically meaningful effect on behavioral loyalty.

The researches in the literature indicate that the factors related to the product and the factors unrelated to the product have effect on the perceived benetifs, psychological commitment and behavioral loyalty. Perceived benefits comprise of some factors including group acceptance, escape, socialization, amusement and nostalgia. For instance; Bauer et al. (2005) came to the conclusion that the factors unrelated to the product had more effects on the perceived benefits, psychological commitment and behavioral loyalty than the factors related to the product did. Gençer et al. (2012) determined that social interaction motive which means socialization benefit had a significant effect 
91 Factors Affecting Brand Loyalty in Football: An Applıcatıon On ... Turkish Super League

on sport consumption. Salman and Giray (2010) determined the effects of the perceived benefit factors such as excitement sharing, taking pleasure, aesthetic, and amusement on loyalty towards football team. The hypotheses established in that vein are described below:

$\mathrm{H}_{4} \mathrm{c}_{1}$ : Perceived benefits have a statistically meaningful effect on psychological commitment.

$\mathrm{H}_{4} \mathrm{c}_{2}$ : Perceived benefits have a statistically meaningful effect on behavioral loyalty.

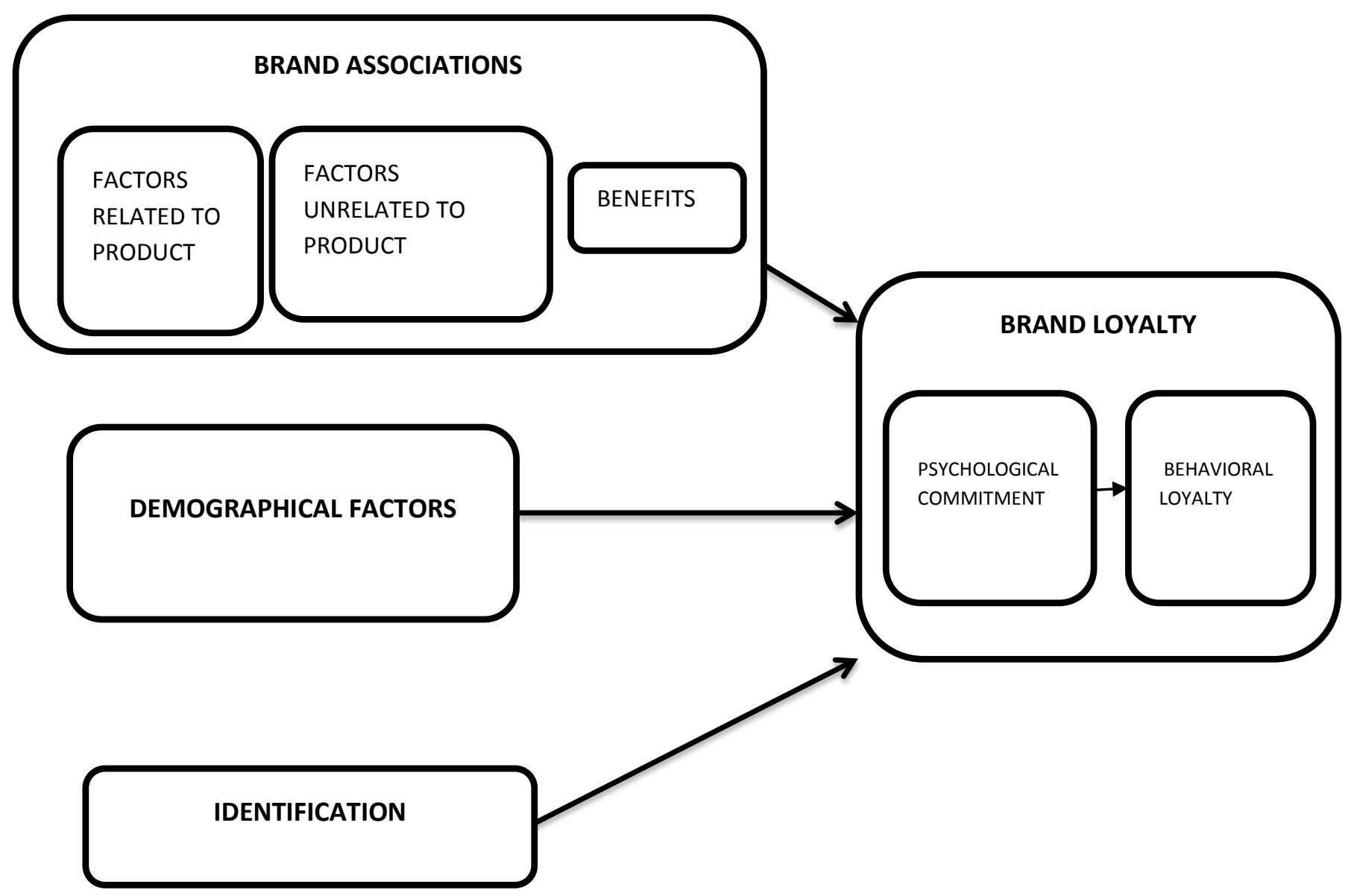

Figure I: Model of The Research

\section{METHODOLOGY}

\section{III.I. Research Design and Data Collection}

The population of this research comprises of 3537 students studying at the Faculty of Economics and Business Administration enrolling in the spring period of 2013-2014 in Bülent Ecevit University. Considering that brand loyalty towards the football clubs may alter according to gender and education level, quota sampling method is applied in this research. To calculate the size of the sample, the below formula indicated by Özdamar (2003:116-118) which is used in case the population is definite is applied: 
$\mathrm{n}=\left(\mathrm{N} \cdot \mathrm{P} \cdot \mathrm{Q} \cdot \mathrm{Z}^{2} \alpha\right) /\left((\mathrm{N}-1) \cdot \mathrm{d}^{2}\right)$

According to the information derived from the formula, although the minimum size of the sample must include 384 participants, to increase the reliability and validity of the research by decreasing type i error, it is aimed to reach to the participants as many as possible. In that vein, 662 participants were reached for this research and 105 participants were eliminated as they were not supporters of The Big Four. In this way, 557 students were found to be the supporters of The Big Four.

\section{III.II. Measures}

In this research, questionaire technique was conducted in data collection. In the questionaire form, to measure brand loyalty, psychological commitment scale and behavioral loyalty scale were used. To measure brand connotations, benefits scale, the factors related to product scale and factors unrelated to product scale were also used. In addition to these scales, to measure the identification of the supporters with the football clubs, Sport Spectator Identification Index was also used. The statements of each scales were adjusted by considering football as a product. The statements of the brand loyalty scales and brand connotations scales were prepared by making compilation from the researches of Bauer et al. (2005), Gladden and Funk (2002), and Koç (2008). To measure the identification with the mentioned football clubs, the Sport Spectator Identification Index developed by Wann and Branscombe (1993) and of which reliability and validity were proved by Günay and Tiryaki (2003) was used in this research.

\section{III.III. Measurement Model and Analysis}

First of all, to determine the internal reliability of the scales' statements, the reliability analysis was applied for each scales. The Cronbach's Alpha coefficients of each scales were determined in between 0,898-0,953, which means that each scales are highly reliable. Then the exploratory factor analysis of the scale statements was applied and the factors derived from the analysis were used for the research's variables**. Finally, Multiple Linear Regression Analysis was applied to find out the factors considered to effect the dependent variable, brand loyalty, by using SPSS 22 packet program.

\section{FINDINGS}

The results indicate that $45,5 \%$ of the participants are Galatasaray F.C. supporters, 31,9\% of the participants are Fenerbahçe F.C. supporters, 15,4\% of the participants are Beşiktaş F.C. supporters, $2 \%$ of the participants are Trabzonspor F.C. supporters, $16 \%$ of the participants are non

\footnotetext{
** The reliability analyses and exploratory factor analyses tables for each scales were shown in Appendix A and APPENDIX B.
} 
supporters, and 2,9\% of the participants are the supporters of the other football clubs except from the "Big Four”. Due to the fact that only the Big Four supporters were taken into account for the research, the non supporters and the supporters of the other football clubs except from the Big Four were eliminated.

The results also show that $55,1 \%$ of the participants are women while $44,9 \%$ of the participants are men. In addition, 38,5\% of the participants are freshmen, $21 \%$ of the participants are sophomores, $16,8 \%$ of the participants are sophisters, and $23,7 \%$ of the participants are seniors. It is seen that $52,3 \%$ of the participants come from the big cities while $35,8 \%$ of the participants come from the cities, and $11,9 \%$ of the participants come from the countryside. The data about the monthly spending of the participants indicate that $19,6 \%$ of the participants spend 300 TL or below, $39,6 \%$ of the participants spend in between 301 TL-500 TL, 37,2\% of the participants spend in between 501 TL$1000 \mathrm{TL}$, and 3,5\% of the participants spend above 1000 TL.

Due to the fact that brand loyalty was measured in both psychological and behavioral dimensions, the Multiple Linear Regression Analysis was applied for both psychological commitment and behavioral loyalty.

\section{Table I}

The Effects of the Variables on Psychological Commitment

\begin{tabular}{|c|c|c|c|c|c|c|c|}
\hline Hypotheses & $\begin{array}{c}\text { Independent } \\
\text { Variables }\end{array}$ & $\begin{array}{l}\text { Standard } \\
\text { Beta }\end{array}$ & Correlations & Std. Error & $\mathrm{t}$ & $\mathrm{p}$ & Result \\
\hline $\mathrm{H} 2_{\mathrm{a}}$ & Identification & 0,384 & 0,721 & 0,027 & 13,997 & 0,000 & Accept \\
\hline $\mathrm{H}_{\mathrm{a} 1}$ & $\begin{array}{l}\text { Football } \\
\text { Club }\end{array}$ & 0,004 & 0,159 & 0,021 &,- 178 & 0,859 & Reject \\
\hline $\mathrm{H} 3_{\mathrm{a} 2}$ & Gender & 0,107 & 0,343 & 0,045 & 4,787 & 0,000 & Accept \\
\hline $\mathrm{H}_{\mathrm{a} 3}$ & $\begin{array}{l}\text { Education } \\
\text { Level }\end{array}$ & 0,016 & 0,005 & 0,018 & 744 & 0,457 & Reject \\
\hline $\mathrm{H}_{\mathrm{a} 4}$ & $\begin{array}{l}\text { Place of } \\
\text { Living }\end{array}$ & 0,033 & 0,175 & 0,031 & $-1,557$ & 0,120 & Accept \\
\hline $\mathrm{H}_{\mathrm{a} 5}$ & $\begin{array}{l}\text { Monthly } \\
\text { Spending }\end{array}$ & 0,052 & 0,129 & 0,026 & 2,491 & 0,013 & Accept \\
\hline $\mathrm{H} 4_{\mathrm{a} 1}$ & $\begin{array}{l}\text { Factors } \\
\text { Related to } \\
\text { Product }\end{array}$ & 0,142 & 0,611 & 0,035 & 4,080 & 0,000 & Accept \\
\hline $\mathrm{H} 4_{\mathrm{b} 1}$ & $\begin{array}{l}\text { Factors } \\
\text { Unrelated to } \\
\text { Product }\end{array}$ & 0,126 & 0,633 & 0,037 & 3,388 & 0,001 & Accept \\
\hline $\mathrm{H} 4_{\mathrm{c} 1}$ & Benefits & 0,309 & 0,770 & 0,033 & 9,271 & 0,000 & Accept \\
\hline
\end{tabular}


It is seen that in Table I, standard beta coefficients were used. This is due to the fact that the multiple linear regression analysis was applied on the factors derived from the factor analysis. It is seen that "identification" variable has the highest coefficient which is 0,384 ; and the "benefits" variable has the second highest coefficient which is 0,309 . These scores indicate that identification and benefits variables are the most effective variables on psychological commitment. On the other hand the statistically effective variables on psychological commitment are found as "benefits" variable ( $\mathrm{p}=, 000 ; \mathrm{p}<, 05)$, “factors related to product” variable $(\mathrm{p}=, 000 ; \mathrm{p}<, 05)$, “factors unrelated to product” variable $(\mathrm{p}=, 001 ; \mathrm{p}<, 05)$, “identification” variable $(\mathrm{p}=, 000 ; \mathrm{p}<, 05)$, “gender” variable ( $\mathrm{p}=, 000 ; \mathrm{p}<, 05)$, “monthly spending” variable $(\mathrm{p}=, 013 ; \mathrm{p}<, 05)$.

\section{Table II}

\section{The Effects of the Variables on Behavioral Loyalty}

\begin{tabular}{|c|c|c|c|c|c|c|c|}
\hline Hypotheses & $\begin{array}{c}\text { Independent } \\
\text { Variables }\end{array}$ & $\begin{array}{c}\text { Standard } \\
\text { Beta }\end{array}$ & Correlations & Std. Error & $\mathrm{t}$ & $\mathrm{p}$ & Result \\
\hline H1 & $\begin{array}{r}\text { Psychological } \\
\text { Commitment }\end{array}$ & 0,269 & 0,815 & 0,030 & 8,884 & 0,000 & Accept \\
\hline $\mathrm{H} 2_{b}$ & Identification & 0,064 & 0,668 & 0,024 & 2,641 & 0,008 & Accept \\
\hline $\mathrm{H} 3_{\mathrm{b} 1}$ & Football Club & 0,009 &,- 155 & 0,016 &,- 569 & 0,570 & Reject \\
\hline $\mathrm{H} 3_{\mathrm{b} 2}$ & Gender & 0,078 & 0,365 & 0,035 & 4,396 & 0,000 & Accept \\
\hline $\mathrm{H} 3_{\mathrm{b} 3}$ & $\begin{array}{c}\text { Education } \\
\text { Level }\end{array}$ & 0,046 & 0,057 & 0,014 & 2,802 & 0,005 & Accept \\
\hline $\mathrm{H}_{\mathrm{b}} \mathrm{b}$ & $\begin{array}{l}\text { Place of } \\
\text { Living }\end{array}$ & 0,009 &,- 111 & 0,024 & ,565 & 0,573 & Reject \\
\hline $\mathrm{H} 3_{b 5}$ & $\begin{array}{l}\text { Monthly } \\
\text { Spending }\end{array}$ & 0,050 & 0,136 & 0,020 & 3,034 & 0,003 & Accept \\
\hline $\mathrm{H} 4_{\mathrm{a} 2}$ & $\begin{array}{l}\text { Factors } \\
\text { Related to } \\
\text { Product }\end{array}$ & 0,094 & 0,608 & 0,027 & 3,427 & 0,001 & Accept \\
\hline $\mathrm{H} 4_{\mathrm{b} 2}$ & $\begin{array}{c}\text { Factors } \\
\text { Unrelated to } \\
\text { Product }\end{array}$ & 0,084 & 0,594 & 0,029 & $-2,912$ & 0,004 & Accept \\
\hline $\mathrm{H} 4_{\mathrm{c} 2}$ & Benefits & 0,602 & 0,884 & 0,027 & 21,916 & 0,000 & Accept \\
\hline
\end{tabular}

It can be seen in Table II that "benefits" variable has the highest coefficient which is 0,602; and the "psychological commitment" variable has the second highest coefficient which is 0,269. In other words, the most effective variables on behavioral loyalty are found as "benefits" variable and "psychological commitment" variable. On the other hand the statistically effective variables on behavioral loyalty are found as "benefits" variable $(\mathrm{p}=, 000 ; \mathrm{p}<, 05)$, "factors related to product" variable $(p=, 001 ; p<, 05)$, “factors unrelated to product” variable $(p=, 004 ; p<, 05)$, “identification” variable ( $p=, 008 ; p<, 05)$, “gender” variable $(p=, 000 ; p<, 05)$, “education level” variable ( $p=, 05$; $\mathrm{p} \leq, 05)$, "monthly spending" variable $(\mathrm{p}=, 003 ; \mathrm{p}<, 05)$, and "psychological commitment" variable $(\mathrm{p}=, 00 ; \mathrm{p}<, 05)$. 


\section{DISCUSSION}

\section{V.I. Summary of Findings}

As a result of the multiple regression analysis, it was found that brand associations, identification, gender and monthly spending variables are statistically effective variables on psychological commitment while football club, education level and place of living variables are not statistically effective variables on psychological commitment. "Benefits" variable and “identification” variable were found to be the most effective variables on psychological commitment. On the other hand, it was found that brand associations, identification, gender, education level, monthly spending and psychological commitment are statistically effective variables on behavioral loyalty while football club and place of living variables are not statistically effective variables on behavioral loyalty. "Benefits” variable and "psychological commitment” variable were found to be the most effective variables on behavioral loyalty.

\section{V.II. Managerial Implications}

Research results indicate that the mentioned football clubs should emphasize on brand associations and identification to develop brand loyalty since the factors related to product, the factors unrelated to product, and benefits variables are remarkably effective in the way of brand loyalty development towards the football clubs. In order to improve the functional and social benefits received by the supporters, the football clubs should improve the physical conditions of the clubs such as stadiums, and facilities that will provide the supporters feeling of socialisation and sense of belonging resulting psychological satisfaction and brand loyalty among the supporters towards the football clubs. Besides, football clubs should not consider the supporters only as one of the material resources of the clubs. In that vein, the football clubs' factors related to product such as the coach, the managers, and the footballers should develop a strong psychological relationship with the supporters. The football clubs should realise the brand promise which stands for winning the matches and becoming champion as much as possible in order not to disappoint the supporters who are loyal to the clubs from the heart. In this way, it becomes easier for the clubs to maintain the brand image of the clubs in the eyes of the supporters which will also bring and maintain brand loyalty. The behavioral loyalty towards the football clubs also increases the material gain of the clubs since the behaviorally loyal supporters are tend to purchase the licenced products of the clubs and/or watch the match at the stadiums. The management of the club becomes able to realise the brand promise inside the clubs such as paying the wages on time which will also increase the motivation of the footballers. The motivated footballers are tend to increase their performances which will increase the perceived 
benefits of the supporters. In this way both the internal customers and the external customers of the football clubs simultaneously win.

It is obvious that Turkish football and Turkish league have not become a brand yet even they have a high level of brand loyalty inside. The factors related to product and the factors unrelated to product are also very effective in building a strong brand image for the mentioned football clubs. In that vein, to conduct an organizational social responsibility projects may increase the brand awareness of the football clubs which will bring brand loyalty as well in both national and international contents. Besides, managing the football clubs by depending on transparency principle may also strenghten the brand image of the football clubs which will also provide a strong brand loyalty.

\section{V.III. Theoretical Implications}

The research results indicate that psychological commitment has a statistically meaningful effect on behavioral loyalty. So H1 is accepted for this research. In other words, the psychological commitment of The Big Four's supporters affects their behavioral loyalty such as buying from the football clubs' stores, watching the football clubs' channels, buying ticket to watch the match in the stadiums, etc. This result supports the literature (Oliver, 1999; Dick ve Basu, 1994) indicating that psychological commitment is a precessor of behavioral loyalty which means that attitudes are also precessors of behaviors. The results are also compatible with the results of Bee and Havitz (2010) and Tzetzis and Tachis (2013) indicating that psychological commitment of the football fans to the team affect behavioral loyalty of the fans. On the other hand, identification also has a statistically meaningful effect on both psychological commitment and behavioral loyalty. So, both $\mathrm{H} 2$ a and $\mathrm{H} 2$ b are accepted for this research. This result is also parallel to the result indicated in the literature that identified supporters become more loyal to the football clubs (Bhattarcharya ve Sen, 2003). The result is also compatible with the results of Çiftyıldız (2015), Enginkaya (2014), Torlak et al. (2014), and Stevens and Rosenberger (2012) indicating that identification with the team affects both psychological commitment and behavioral loyalty towards football clubs.

The result showing that identification is the major determinant of psychological commitment is also compatible with the result of Wu et al. (2012) indicating that team identification is the major determinant of fans' loyalty intentions. In the research, demographic variables' effects on brand loyalty were also investigated, and it was found that education level did not have statistically meaningful effect on psychological commitment which is in contrast to the results revealed by Kurtuldu and Çilingir (2009). Gender and monthly spending of the supporters were found to be effective variables on both psychological commitment and behavioral loyalty. This result is 
compatible with the results of Salman and Giray (2010) indicating that men are more loyal than women to the football clubs, and the results of Demirel et al. (2007 indicating that as income of the fans decreases psychological commitment with the football clubs increases. Besides, the place of living of the participants and the supported football clubs variables were also found to have no statistically meaningful effect on behavioral loyalty. Due to the fact that there are only a few researches that can be compared with this result, this result can be considered as a contribution to the literature. On the other hand, brand associations variables are found to have statistically meaningful effects on both psychological commitment and behavioral loyalty which support the results revealed by Bauer et al. (2005). So, H3 and H4 were accepted. In other words, the football clubs' tangible factors such as stadiums, logos, uniforms; intangible factors such as game, success and values of the clubs, and benefits perceived by the supporters from the football clubs are effective on both psychological commitment and behavioral loyalty of the supporters. This result is also compatible with the results of Funk et al. (2012), Aycan et al. (2009), Gencer et al. (2012), and Salman and Giray (2010) indicating that tangible motivational factors, intangible motivational factors and benefits have effect on loyalty to the football clubs.

\section{V.IV. Limitations and Future Research}

This research was only conducted with the "Big Four" supporters studying at the Faculty of Economics and Administrative Sciences in Bülent Ecevit University. Due to the fact that the participants in the research sample had almost the same years of age and marital status, the effect of age and marital status on brand loyalty could not be evaluated for this research. To generalise the results, this research should be conducted in the other cities and should not be limited to the students. In this research, a model was constituted by including brand connotations, identification, and demographic factors thought to be effective on brand loyalty. For future researches, the model can be developed by researching the effects of the elements of brand equity such as brand awareness, brand image, and perceived quality on brand loyalty which will reveal more comprehensive and generalizable results. 


\section{REFERENCES}

Aaker, David A. (1991). Managing brand equity: Capitalizing on the value of a brand name. New York: The Free Press.

Arkonaç, Sibel A. (2001). Sosyal psikoloji. İstanbul: Alfa Yayınları.

Assael, H. (1998). Consumer behavior and marketing action. Ohio: South Western College Publishing.

Aycan, Ali, Ercan Polat \& Yılmaz Uçan (2009). Takım özdeşleşme düzeyi ile profesyonel futbol müsabakalarına seyirci olarak katılım kararını etkileyen değişkenler arasındaki ilişkinin incelenmesi. SPORMETRE Beden Ĕ̆itimi ve Spor Bilimleri Dergisi, 7 (4): 169-174.

Back, K.J. (2005). The effects of image congruence on customers brand loyalty in the upper middleclass hostel industry. Journal of Hospitality and Tourism Research, 29(4): 448-467.

Bauer, Hans H., Nicola E. Sauer \& Stefanie Exler (2005). The loyalty of german soccer fans: Does a team's brand image matter? International Journal of Sports Marketing and Sponsorship, 7(1):14-22.

Bee, Colleen C. \& Mark E. Havitz (2010). Exploring the relationship between involvement, fan attraction, psychological commitment and behavioral loyalty in a sport spectator context. International Journal of Sports Marketing and Sponsorship, 11 (2): 37-54.

Belk, R. (1988). Possessions and the extended self. Journal of Consumer Research, 15(2): 139-168.

Bhattacharya, C.B. \& S. Sen (2003). Consumer-company identification: A framework for understanding consumers’ relationships with companies. Journal of Marketing, 67: 76-88.

Brooks, Christine M. (1994). Marketing, competitive business strategies for sports. New Jersey: Prentice Hall.

Çiftyıldız, Saim Saner (2015). Takımların lisanslı ürünleri bağlamında, takımla özdeşleşme, duygusal marka bağlılığı ve satın alma niyeti olguları arasındaki ilişkileri incelemeye yönelik bir uygulama. Elektronik Sosyal Bilimler Dergisi, 14 (53): 232-241.

Demirel, Mehmet, Bengü Güven Karahan \& Hüseyin Ünlü (2007). Farklı üniversitelerdeki spor taraftarlarının takımları ile özdeşleşme düzeyleri. Niğde Üniversitesi Beden Eğitimi ve Spor Bilimleri Dergisi, 1(2):76-86.

Dick, A. \& K. Basu (1994). Customer loyalty: Towards an integrated conceptual framework. Journal of the Academy of Marketing Science, 22: 99-113.

Enginkaya, Ebru (2014). Futbol taraftarlarının sponsor markalara ilişkin tutum, satın alma niyeti ve takımla özdeşleşmeleri arasındaki ilişki. Marmara Üniversitesi İ.I.B. Dergisi, 36 (2): 145-158.

Erdoğan, İrfan (2008). Futbol ve futbolu inceleme üzerine. İletişim Kuram ve Araştırma Dergisi, 26: $1-58$. 
Funk, Daniel C., Anthony Beaton \& Kostas Alexandris (2012). Sport consumer motivation: Autonomy and control orientations that regulate fan behaviours. Sport Management Review, 15 (2012): 355-367.

Genar (2004). Türk toplumunda futbol algısı araştırması. Haziran 2004.

Gençer, R. Timuçin, Olcay Kiremitçi, Ali Aycan, Erdinç Demiray \& Volkan Unutmaz (2012). Profesyonel futbol takımı seyircilerinin spor tüketimine yönelik güdüleri ve bağlılık noktaları arasındaki ilişki. Ege Akademik Bakış, 12 (2012): 41-53.

Gladden, James M. \& Daniel F. Funk (2002). Developing an understanding of brand associations in team sport: Empirical evidence from customers of professional sport. Journal of Sport Management, 16: 54-81.

Gounaris, S. \& V. Stathakopoulos (2004). Antecedents and consequences of brand loyalty: An empirical study. Journal of Brand Management, 11(4): 283-306.

Günay, Necla \& Şefik Tiryaki (2003). Spor taraftarı özdeşleşme ölçeğinin (stöö) geçerlik ve güvenirlik çalışması. Hacettepe Spor Bilimleri Dergisi, 14(1):14-26.

Jacoby, J. \& R. Chesnut (1978). Brand loyalty measurement and management. New York: John Willey.

Keller, Kevin L. (1993). Conceptualizing, measuring, and managing customer based brand equity. Journal of Marketing, 57(1):1-22.

Koç, Nevhan (2008). Marka çağrışımlarının marka sadakati üzerindeki etkisi: Trabzonspor kulübü taraftarlarl üzerinde bir uygulama. Unpublished master dissertation, Karadeniz Teknik Üniversitesi Sosyal Bilimler Enstitüsü, Trabzon.

Kurtuldu, Hüseyin \& Zühal Çilingir (2009). Gerçek ve ideal özkimlik uyumunun marka sadakati üzerindeki etkisi: Sigara sektöründe bir uygulama. Atatürk University Journal of Economic \& Administrative Sciences, 23(1): 247-263.

Madrigal, R. (2000). The influence of social alliances with sport teams on intentions to purchase corporate sponsors’ products. Journal of Advertising, 29(4): 13-24.

Odabaşı, Yavuz (2006). Postmodern pazarlama. İstanbul: MediaCat Yayınları.

Odin, Y., N. Odin \& P. Florence (2001). Conceptual and operational aspects of brand loyalty: An emprical investigation. Journal of Business Research, 53: 75-84.

Oliver, R.L. (1999). Whence customer loyalty. Journal of Marketing, 63: 33-44.

Özdamar, K. (2003). Modern bilimsel araştırma yöntemleri. Eskişehir: Kaan Kitabevi.

Salman, G. Gültekin (2008). Profesyonel futbol kulüplerinin hizmet kalitesi ile taraftar memnuniyeti ve taraftar tipolojileri arasındaki ilişki. Unpublished doctorate dissertation, Marmara Üniversitesi Sosyal Bilimler Enstitüsü, İstanbul. 
Salman, Gülberk Gültekin \& Caner Giray (2010). Bireylerin futbol taraftarı olmasını etkileyen güdüler ile sadakat arasındaki ilişki: Fernerbahçe taraftarları üzerine bir uygulama. Öneri Dergisi, 9(33): 89-97.

Stevens, Shawn \& Philip J. Rosenberger (2012). The influence of involvement, following sport and fan identification on fan loyalty: An Australian perspective. International Journal of Sports Marketing \& Sponsorship, 13(3):220-234.

Tachis, Stavros \& George Tzetzis (2015). The relationship among fans’ involvement, psychological commitment, and loyalty in professional team sports. International Journal of Sport Management, Recreation \& Tourism, 18:1-25.

Trail, G.T. \& J.D. James (2001). The motivation scale for sport consumption: Assessment of the scale’s psychometric properties. Journal of Sport Behavior, 24(1).

Torlak, Ömer, Behçet Yalın Özkara \& Volkan Doğan (2014). Taraftarların takımlarla özdeşleşme düzeylerinin, takımların lisanslı ürünlerine yönelik kalite algısı ve satın alma niyetine etkisi. Ege Akademik Bakış, 14 (1): 73-81.

Wann, D.L. \& N.R. Branscombe (1993). Sports fans: Measuring degree of identification with their team. International Journal of Sport Psychology, 24, 1:17.

Wann, D.L. \& N.R. Branscombe (1995). Influence of identification with a sports team on objective knowledge and subjective beliefs. International Journal of Sport Psychology, (26): 551-567.

Wann, Daniel L. \& Matthew S. Wiggins (1999). Preliminary investigation of the confidence of sport spectators: Importance of time, difficulty of the game, and team identification. Perceptual and Motor Skills, (89): 305-310.

Wu, Shih-Hao, Ching-Yi Daphne Tsai \& Chung-Chieh Hung (2012). Toward team or player? How trust, vicarious achievement motive, and identification affect fan loyalty. Journal of Sport Management, 26 (2): 177-191.

http://www.deloitte.com-Deloitte Football Money League 2014, (Date of Access :31.01.2014). 
101 Factors Affecting Brand Loyalty in Football: An Applıcatıon On ... Turkish Super League

\section{APPENDIX A}

Table I: Reliability Analysis for Identification Scale (After Omitting $\mathbf{X}_{3}$ From the Scale)

\begin{tabular}{cc}
\hline $\begin{array}{c}\text { Cronbach Alpha Coefficient } \\
\text { Items }\end{array}$ & $\begin{array}{c}\mathbf{0 , 9 0 9} \\
\text { Cronbach's Alpha If Items Deleted }\end{array}$ \\
\hline $\mathrm{X}_{1}$ & 0,903 \\
$\mathrm{X}_{2}$ & 0,906 \\
$\mathrm{X}_{4}$ & 0,899 \\
$\mathrm{X}_{5}$ & 0,893 \\
$\mathrm{X}_{6}$ & 0,897 \\
$\mathrm{X}_{7}$ & 0,892 \\
$\mathrm{X}_{8}$ & 0,888 \\
$\mathrm{X}_{9}$ & 0,904 \\
\hline
\end{tabular}

Table II: Reliability Analysis for Factors Related to Product Scale

\begin{tabular}{cc}
\hline $\begin{array}{c}\text { Cronbach Alpha Coefficient } \\
\text { Items }\end{array}$ & $\mathbf{0 , 8 9 8}$ \\
$\mathrm{U} 1_{\mathrm{a}}$ & Cronbach's Alpha If Items Deleted \\
$\mathrm{U} 2_{\mathrm{a}}$ & 0,880 \\
$\mathrm{U} 3_{\mathrm{a}}$ & 0,854 \\
$\mathrm{U} 4_{\mathrm{a}}$ & 0,860 \\
$\mathrm{U} 5_{\mathrm{a}}$ & 0,895 \\
\hline
\end{tabular}

Table III: Reliability Analysis for Factors Unrelated to Product Scale

\begin{tabular}{cc}
\hline $\begin{array}{c}\text { Cronbach Alpha Coefficient } \\
\text { Items }\end{array}$ & $\mathbf{0 , 8 9 8}$ \\
$\mathrm{U} 1_{\mathrm{b}}$ & Cronbach's Alpha If Items Deleted \\
$\mathrm{U} 2_{\mathrm{b}}$ & 0,944 \\
$\mathrm{U} 3_{\mathrm{b}}$ & 0,936 \\
$\mathrm{U} 4_{\mathrm{b}}$ & 0,931 \\
$\mathrm{U} 5_{\mathrm{b}}$ & 0,932 \\
$\mathrm{U} 6_{\mathrm{b}}$ & 0,935 \\
\hline
\end{tabular}

Table IV: Reliability Analysis for Benefits Scale

\begin{tabular}{cc}
\hline $\begin{array}{c}\text { Cronbach Alpha Coefficient } \\
\text { Items }\end{array}$ & $\begin{array}{c}\mathbf{0 , 8 9 8} \\
\text { Cronbach's Alpha If Items Deleted }\end{array}$ \\
\hline B1 & 0,915 \\
B2 & 0,925 \\
B3 & 0,913 \\
B4 & 0,911 \\
B5 & 0,915 \\
B6 & 0,912 \\
\hline
\end{tabular}




\section{APPENDIX A-Cont'd}

Table V: Reliability Analysis for Psychological Commitment Scale

\begin{tabular}{cc}
\hline $\begin{array}{c}\text { Cronbach Alpha Coefficient } \\
\text { Items }\end{array}$ & $\begin{array}{c}\mathbf{0 , 8 9 8} \\
\text { Cronbach's Alpha If Items Deleted }\end{array}$ \\
P1 & 0,946 \\
P2 & 0,943 \\
P3 & 0,945 \\
P4 & 0,944 \\
P5 & 0,947 \\
P6 & 0,948 \\
P7 & 0,949 \\
P8 & 0,950 \\
\hline
\end{tabular}

Table VI: Reliability Analysis for Behavioral Loyalty Scale

\begin{tabular}{cc}
\hline $\begin{array}{c}\text { Cronbach Alpha Coefficient } \\
\text { Items }\end{array}$ & $\begin{array}{c}\mathbf{0 , 8 9 8} \\
\text { Cronbach's Alpha If Items Deleted }\end{array}$ \\
\hline D1 & 0,927 \\
D2 & 0,921 \\
D3 & 0,922 \\
D4 & 0,918 \\
D5 & 0,921 \\
D6 & 0,919 \\
D7 & 0,919 \\
D8 & 0,924 \\
\hline
\end{tabular}


103 Factors Affecting Brand Loyalty in Football: An Applıcatıon On ... Turkish Super League

\section{APPENDIX B}

Table VII: Identification Scale Exploratory Factor Analysis

\begin{tabular}{|c|c|c|c|c|c|c|}
\hline \multicolumn{3}{|c|}{$\begin{array}{c}\text { KMO } \\
\text { X² }^{2} \text { Statistics (Significance) } \\
\text { Initial Eigenvalues } \\
\end{array}$} & \multicolumn{4}{|c|}{$\begin{array}{c}\mathbf{0 , 9 0 7} \\
\text { 3365,895 [0.000] } \\
\text { Derived Squared Weight Sum } \\
\end{array}$} \\
\hline Component & Sum & Variance (\%) & $\begin{array}{c}\text { Cumulative } \\
\text { (\%) }\end{array}$ & Sum & Variance (\%) & $\begin{array}{c}\text { Cumulative } \\
(\%)\end{array}$ \\
\hline 1 & 5,210 & 57,893 & 57,893 & 5,210 & 57,893 & 57,893 \\
\hline 2 & ,801 & 8,899 & 66,793 & & & \\
\hline 3 & ,654 & 7,262 & 74,055 & & & \\
\hline 4 & ,572 & 6,356 & 80,411 & & & \\
\hline 5 & ,541 & 6,008 & 86,419 & & & \\
\hline 6 & ,458 & 5,092 & 91,511 & & & \\
\hline 7 & 317 & 3,519 & 95,030 & & & \\
\hline 8 & ,260 & 2,886 & 97,917 & & & \\
\hline 9 & ,188 & 2,083 & 100,00 & & & \\
\hline
\end{tabular}

Table VIIa: Correlations for Identification Scale

\begin{tabular}{ll}
\hline Items & Component \\
& 1 \\
\hline X1 & 0,740 \\
X2 & 0,698 \\
X3 & 0,578 \\
X4 & 0,764 \\
X5 & 0,820 \\
X6 & 0,784 \\
X7 & 0,833 \\
X8 & 0,866 \\
\hline
\end{tabular}

Table VIII: Factors Related to Product Scale Factor Analysis

\begin{tabular}{|c|c|c|c|c|c|c|}
\hline \multicolumn{3}{|c|}{$\begin{array}{c}\text { KMO } \\
\text { X² }^{2} \text { Statistics (Significance) } \\
\text { Initial Eigenvalues } \\
\end{array}$} & \multicolumn{4}{|c|}{$\begin{array}{c}\mathbf{0 , 8 5 1} \\
\mathbf{2 2 2 8 , 4 8 5 [ 0 . 0 0 0 ]} \\
\text { Derived Squared Weight Sum }\end{array}$} \\
\hline Component & Sum & Variance (\%) & $\begin{array}{c}\text { Cumulative } \\
\text { (\%) }\end{array}$ & Sum & Variance (\%) & $\begin{array}{c}\text { Cumulative } \\
\text { (\%) }\end{array}$ \\
\hline 1 & 3,580 & 71,606 & 71,606 & 3,580 & 71,606 & 71,606 \\
\hline 2 & 0,662 & 13,248 & 84,854 & & & \\
\hline 3 & 0,354 & 7,078 & 91,932 & & & \\
\hline 4 & 0,219 & 4,372 & 96,304 & & & \\
\hline 5 & 0,185 & 3,696 & 100,000 & & & \\
\hline
\end{tabular}




\section{APPENDIX B-Cont'd}

Table VIII a: Correlations for Factors Related to Product Scale

\begin{tabular}{ll}
\hline Items & Component \\
& 1 \\
\hline $\mathrm{U} 1_{\mathrm{A}}$ & 0,838 \\
$\mathrm{U} 2_{\mathrm{A}}$ & 0,915 \\
$\mathrm{U} 3_{\mathrm{A}}$ & 0,899 \\
$\mathrm{U} 4_{\mathrm{A}}$ & 0,773 \\
$\mathrm{U} 5_{\mathrm{A}}$ & 0,797 \\
\hline
\end{tabular}

Table IX: Factors Unrelated to Product Factor Analysis

\begin{tabular}{|c|c|c|c|c|c|c|}
\hline \multicolumn{3}{|c|}{$\begin{array}{c}\text { KMO } \\
\mathrm{X}^{2} \text { Statistics (Significance) } \\
\text { Initial Eigenvalues } \\
\end{array}$} & \multicolumn{4}{|c|}{$\begin{array}{c}0,925 \\
\text { 3663,553 [0.000] } \\
\text { Derived Squared Weight Sum }\end{array}$} \\
\hline Component & Sum & Variance (\%) & $\begin{array}{c}\text { Cumulative } \\
\text { (\%) }\end{array}$ & Sum & Variance (\%) & $\begin{array}{c}\text { Cumulative } \\
\text { (\%) }\end{array}$ \\
\hline 1 & 4,738 & 78,966 & 78,966 & 4,738 & 78,966 & 78,966 \\
\hline 2 & 0,400 & 6,668 & 85,634 & & & \\
\hline 3 & 0,271 & 4,525 & 90,159 & & & \\
\hline 4 & 0,220 & 3,659 & 93,818 & & & \\
\hline 5 & 0,209 & 3,481 & 97,299 & & & \\
\hline 6 & 0,162 & 2,701 & 100,00 & & & \\
\hline
\end{tabular}

Table IX $\mathrm{X}_{\mathrm{a}}$ : Correlations for Factors Unrelated to Product Scale

\begin{tabular}{ll}
\hline Items & Component \\
& 1 \\
\hline $\mathrm{U} 1_{\mathrm{B}}$ & 0,837 \\
$\mathrm{U} 2_{\mathrm{B}}$ & 0,892 \\
$\mathrm{U} 3_{\mathrm{B}}$ & 0,920 \\
$\mathrm{U} 4_{\mathrm{B}}$ & 0,913 \\
$\mathrm{U} 5_{\mathrm{B}}$ & 0,894 \\
$\mathrm{U} 6_{\mathrm{B}}$ & 0,874 \\
\hline
\end{tabular}

Table X: Benefits Scale Factor Analysis

\begin{tabular}{|c|c|c|c|c|c|c|}
\hline \multicolumn{3}{|c|}{$\begin{array}{c}\text { KMO } \\
\mathrm{X}^{2} \text { Statistics (Significance) } \\
\text { Initial Eigenvalues } \\
\end{array}$} & \multicolumn{4}{|c|}{$\begin{array}{c}\mathbf{0 , 8 7 8} \\
\mathbf{3 1 3 8 , 6 6 3 [ 0 . 0 0 0 ]} \\
\text { Derived Squared Weight Sum }\end{array}$} \\
\hline Component & Sum & Variance (\%) & $\begin{array}{c}\text { Cumulative } \\
\text { (\%) }\end{array}$ & Sum & Variance (\%) & $\begin{array}{c}\text { Cumulative } \\
\text { (\%) }\end{array}$ \\
\hline 1 & 4,433 & 73,890 & 73,890 & 4,433 & 73,890 & 73,890 \\
\hline 2 & 0,539 & 8,979 & 82,870 & & & \\
\hline 3 & 0,329 & 5,479 & 88,349 & & & \\
\hline 4 & 0,291 & 4,844 & 93,193 & & & \\
\hline 5 & 0,271 & 4,522 & 97,714 & & & \\
\hline 6 & 0,137 & 2,286 & 100,00 & & & \\
\hline
\end{tabular}


105 Factors Affecting Brand Loyalty in Football: An Applıcatıon On ... Turkish Super League

\section{APPENDIX B-Cont'd}

Table $X_{a}$ : Correlations for Benefits Scale

\begin{tabular}{ll}
\hline Items & Component \\
& 1 \\
\hline B1 & 0,863 \\
B2 & 0,800 \\
B3 & 0,868 \\
B4 & 0,884 \\
B5 & 0,865 \\
B6 & 0,874 \\
\hline
\end{tabular}

Table XI: Psychological Commitment Scale Factor Analysis

\begin{tabular}{|c|c|c|c|c|c|c|}
\hline \multicolumn{3}{|c|}{$\begin{array}{c}\text { KMO } \\
\mathbf{X}^{2} \text { Statistics (Significance) } \\
\text { Initial Eigenvalues } \\
\end{array}$} & \multicolumn{4}{|c|}{$\begin{array}{l}\mathbf{0 , 9 2 4} \\
\mathbf{5 , 3 7 2}[\mathbf{0 . 0 0 0 ]} \\
\text { quared Weight Sum } \\
\end{array}$} \\
\hline Component & Sum & Variance (\%) & $\begin{array}{c}\text { Cumulative } \\
(\%)\end{array}$ & Sum & Variance (\%) & $\begin{array}{c}\text { Cumulative } \\
\text { (\%) }\end{array}$ \\
\hline 1 & 6,033 & 75,410 & 75,410 & 6,033 & 75,410 & 75,410 \\
\hline 2 & ,620 & 7,748 & 83,158 & & & \\
\hline 3 & ,374 & 4,680 & 87,838 & & & \\
\hline 4 & ,289 & 3,615 & 91,453 & & & \\
\hline 5 & ,223 & 2,787 & 94,240 & & & \\
\hline 6 & ,185 & 2,314 & 96,554 & & & \\
\hline 7 & ,154 & 1,926 & 98,481 & & & \\
\hline 8 & ,122 & 1,519 & 100,000 & & & \\
\hline
\end{tabular}

Table XIa: Correlations for Psychological Commitment Scale

\begin{tabular}{ll}
\hline Items & Component \\
& 1 \\
\hline P1 &, 873 \\
P2 &, 914 \\
P3 &, 889 \\
P4 &, 902 \\
P5 &, 865 \\
P6 &, 850 \\
P7 &, 827 \\
P8 &, 824 \\
\hline
\end{tabular}




\section{APPENDIX B-Cont'd}

Table XII: Behavioral Loyalty Scale Factor Analysis

\begin{tabular}{|c|c|c|c|c|c|c|}
\hline \multicolumn{3}{|c|}{$\begin{array}{c}\text { KMO } \\
\mathbf{X}^{2} \text { Statistics (Significance) } \\
\text { Initial Eigenvalues } \\
\end{array}$} & \multicolumn{4}{|c|}{$\begin{array}{c}\mathbf{0 , 9 0 8} \\
\text { 3996.706 [0.000] } \\
\text { Derived Squared Weight Sum }\end{array}$} \\
\hline Component & Sum & Variance (\%) & $\begin{array}{c}\text { Cumulative } \\
(\%)\end{array}$ & Sum & Variance (\%) & $\begin{array}{c}\text { Cumulative } \\
\text { (\%) }\end{array}$ \\
\hline 1 & 5,402 & 67,521 & 67,521 & 5,402 & 67,521 & 67,521 \\
\hline 2 & ,787 & 9,833 & 77,353 & & & \\
\hline 3 & ,471 & 5,886 & 83,239 & & & \\
\hline 4 & ,403 & 5,037 & 88,276 & & & \\
\hline 5 & ,282 & 3,531 & 91,807 & & & \\
\hline 6 & ,251 & 3,139 & 94,946 & & & \\
\hline 7 & ,230 & 2,881 & 97,827 & & & \\
\hline 8 & ,174 & 2,173 & 100,000 & & & \\
\hline
\end{tabular}

Table XIIa: Correlations for Behavioral Loyalty Scale

\begin{tabular}{ll}
\hline Items & Component \\
& 1 \\
\hline D1 &, 748 \\
D2 &, 822 \\
D3 &, 823 \\
D4 &, 863 \\
D5 &, 831 \\
D6 &, 849 \\
D7 &, 842 \\
D8 &, 789 \\
\hline
\end{tabular}

